\title{
Application of Probabilistic Model to Calculate Probabilities of Escherichia coli 0157:H7 Growth on Polyethylene Cutting Board
}

\author{
Joo-Yeon Lee ${ }^{1}$, Hee-Jin Suk ${ }^{1}$, Heeyoung Lee, Soomin Lee, and Yohan Yoon* \\ Department of Food and Nutrition, Sookmyung Women's University, Seoul 140-742, Korea \\ ${ }^{1}$ Korea Livestock Products HACCP Accreditation Service, Kyounggi-do 430-731, Korea
}

\begin{abstract}
This study calculated kinetic parameters of Escherichia coli $\mathrm{O} 157: \mathrm{H} 7$ and developed a probabilistic model to estimate growth probabilities of $E$. coli $\mathrm{O} 157: \mathrm{H} 7$ on polyethylene cutting boards as a function of temperature and time. The surfaces of polyethylene coupons $(3 \times 5 \mathrm{~cm})$ were inoculated with $E$. coli $\mathrm{O} 157: \mathrm{H} 7 \mathrm{NCCP} 11142$ at $4 \mathrm{Log} \mathrm{CFU} / \mathrm{cm}^{2}$. The coupons were stored at 13 to $35^{\circ} \mathrm{C}$ for $12 \mathrm{~h}$, and cell counts of $E$. coli O157:H7 were enumerated on McConkey II with sorbitol agar every $2 \mathrm{~h}$. Kinetic parameters (maximum specific growth rate, Log CFU/ $\mathrm{cm}^{2} / \mathrm{h}$; lag phase duration, h; lower asymptote, Log $\mathrm{CFU} / \mathrm{cm}^{2}$; upper asymptote, $\log \mathrm{CFU} / \mathrm{cm}^{2}$ ) were calculated with the modified Gompertz model. Of 56 combinations (temperature $\times$ time), the combinations that had $\geq 0.5 \mathrm{Log} \mathrm{CFU} / \mathrm{cm}^{2}$ of bacterial growth were designated with the value of 1 , and the combinations that had increases of $<0.5 \mathrm{Log} \mathrm{CFU} / \mathrm{cm}^{2}$ were given the value 0 . These growth response data were fitted to the logistic regression to develop the model predicting probabilities of E. coli O157:H7 growth. Specific growth rate and growth data showed that $E$. coli $\mathrm{O} 157: \mathrm{H} 7$ cells were grown at $28-35^{\circ} \mathrm{C}$, but there were no obvious growth of the pathogen below $25^{\circ} \mathrm{C}$. Moreover, the developed probabilistic model showed acceptable performance to calculate growth probability of $E$. coli $\mathrm{O} 157: \mathrm{H} 7$. Therefore, the results should be useful in determining upper limits of working temperature and time, inhibiting $E$. coli $\mathrm{O} 157: \mathrm{H} 7$ growth on polyethylene cutting board.
\end{abstract}

Key words: Escherichia coli $\mathrm{O} 157: \mathrm{H} 7$, probabilistic model, predictive model, cutting board

\section{Introduction}

Food safety management system such as Hazard Analysis and Critical Control Point (HACCP) has been recommended to improve food safety in meat industry (Gounadaki et al., 2008). For HACCP system, critical control point is a procedure at which controls can be applied, and a food safety hazard can be prevented or reduced to acceptable levels (Bryan, 1990). In meat cutting plant or butcher's shop handling raw meat as a final product, there is no step to reduce the microbiological hazard. Thus, it is important to reduce the bacterial contaminations such as Salmonella, Escherichia coli O157:H7 and Campylobacter spp. through operational hygiene procedures (FSA, 2011). To maintain the good hygiene practices, temperature is one of the important factors for food safety management in butcher's shops in Korea, and the temperature should

\footnotetext{
*Corresponding author: Yohan Yoon, Department of Food and Nutrition, Sookmyung Women's University, Seoul 140-742, Korea. Tel: 82-2-2077-7585, Fax: 82-2-710-9479, E-mail: yyoon@sookmyung.ac.kr
}

be below $15^{\circ} \mathrm{C}$ in working area of butcher's shops not to allow Salmonella and E. coli O157:H7 growth (QIA, 2009). For this temperature, a refrigeration system needs to be installed for whole working area, but it is very costly for small-scale butcher's shops. Hence, the data for upper limits of temperature and working hours which can inhibit bacterial growth on food-contact surfaces should be useful information for small-scale butcher's shops. If bacterial growth on food-contact surfaces is inhibited at the certain temperature which can be obtained by air conditioning system, the temperature limit could be reestablished at higher than $15^{\circ} \mathrm{C}$ with limited working hour for small-scale butcher's shops.

Food-contact surface is a major concern in food processing because they could be a cross-contamination source for foods, and biofilms are also colonized on foodcontact surfaces and it exhibits increased antimicrobial resistance (Yoon and Sofos, 2008; Zhao et al., 2011). Tang et al. (2011) showed that $44.9 \%$ and $49.3 \%$ of Campylobacter jejuni were transferred from wood and polyethylene cutting boards to chicken fillets.

To describe kinetic behavior of foodborne bacteria on 
food-contact surfaces under different temperatures and time, mathematical modeling is an appropriate tool because mathematical models have been used to estimate kinetic parameters, and the parameters are used to describe kinetic behavior of pathogens (Baranyi and Roberts, 1994; Koutsoumanis et al., 2010). Predictive microbiology has been used to predict inactivation or growth of bacteria, and growth limits of foodborne pathogens in food-like environments and real foods, but not in foodcontact surfaces (Deboosere et al., 2010; Mataragas et al., 2006). Hence, the use of predictive models to estimate the food safety related to food-contact surface should be practical application.

Probabilistic models can be used to predict the probability of bacterial growth under different conditions (Tienungoon et al., 2000). To model interfaces between growth and no growth of pathogenic bacteria at certain level of probability, logistic regression analysis can be a useful method (Koutsoumanis et al., 2004; Ratkowsky and Ross, 1995). The concept of probabilistic model was introduced by Genigeorgis et al. (1971) and Yoon et al. (2011) recently applied the concept to calculate probabilities of Listeria monocytogenes growth or no growth on various ready-to-eat meat and poultry products using data from real foods rather than broth media. The calculated probabilities of growth in many combinations of food-related factors could be practical to establish food safety regulations.

Therefore, the objectives of this study were to describe kinetic behavior of E. coli $\mathrm{O} 157: \mathrm{H} 7$ and to calculate working temperature and time inhibiting E. coli O157:H7 growth on polyethylene cutting board, using a probabilistic model.

\section{Materials and Methods}

\section{Preparation of inoculum}

E. coli O157:H7 NCCP11142 stored as a frozen culture at $-70^{\circ} \mathrm{C}$ was cultured in $10 \mathrm{~mL}$ of tryptic soy broth (TSB; Difco, Becton Dickinson and Company, USA) at $35^{\circ} \mathrm{C}$ for $24 \mathrm{~h}$. The $0.1 \mathrm{~mL}$ of the culture was then transferred into $10 \mathrm{~mL}$ of TSB followed by subculture at $35^{\circ} \mathrm{C}$ for $24 \mathrm{~h}$. Stationary phase cells were harvested by centrifugation (1,912 $\left.\mathrm{g}, 15 \mathrm{~min}, 4^{\circ} \mathrm{C}\right)$, washed, resuspended in phosphate buffered saline (PBS, $\mathrm{pH} 7.4 ; 0.2 \mathrm{~g}$ of $\mathrm{KH}_{2} \mathrm{PO}_{4}, 1.5$ $\mathrm{g}$ of $\mathrm{Na}_{2} \mathrm{HPO}_{4} \cdot 7 \mathrm{H}_{2} \mathrm{O}, 8.0 \mathrm{~g}$ of $\mathrm{NaCl}$, and $0.2 \mathrm{~g}$ of $\mathrm{KCl}$ in $1 \mathrm{~L}$ of distilled water), and diluted in PBS to yield approximately $5 \mathrm{Log} \mathrm{CFU} / \mathrm{mL}$ of inoculum.

\section{Inoculation}

To simulate cutting boards in a butcher's shop, polyethylene coupons $(3 \times 5 \mathrm{~cm})$ were swabbed with fresh pork belly pieces using 10 horizontal and 20 vertical passes (1 pass defined as the down and back motion of the hand), and pork purge was sprayed overhead of coupons using a $1 \mathrm{~L}$ trigger sprayer; pork purge was prepared by mixture of pork belly and sterile distilled water at ratio of 1 to 1 , followed by pummeling (BagMixer ${ }^{\circledR}$, Interscience, France). A volume of $0.1 \mathrm{~mL}$ of $E$. coli $\mathrm{O} 157: \mathrm{H} 7$ inoculum was introduced over one side of coupons with a sterile bent glass rod, left to stand for 15 min under laminar flow for cell attachment. The target inoculation level was 4-5 Log $\mathrm{CFU} / \mathrm{cm}^{2}$. The inoculated coupons were placed on plastic containers with lid open and stored at 13, 15, 20, 25, 28, 30,33 and $35^{\circ} \mathrm{C}$ for $12 \mathrm{~h}$, and pork purge was sprayed over the coupons after $30 \mathrm{~min}$ of inoculation and the same procedure was then applied every hour to simulate smeared purge on cutting boards from repeated fabrication.

\section{Microbiological analysis}

Bacterial cell counts of E. coli $\mathrm{O} 157: \mathrm{H} 7$ on polyethylene coupons were determined every $2 \mathrm{~h}$ for $12 \mathrm{~h}$. To sample surface of coupons, sterile swabs tipped with cotton (Easy swab ${ }^{\circledR}$, Komed Co. Ltd., Korea) were used. Briefly, the cap was removed from the vial containing the swab tip and $10 \mathrm{~mL}$ of a solution $(\mathrm{pH} 7.3 ; 8.0 \mathrm{~g}$ sodium chloride, $0.2 \mathrm{~g}$ potassium chloride, $0.272 \mathrm{~g}$ monopotassium phosphate, $1.42 \mathrm{~g}$ disodium phosphate in $1 \mathrm{~L}$ of distilled water), and the dampened swab with the solution was used to swab the surfaces with 10 horizontal and 20 vertical passes. Decimal dilutions were made with $9 \mathrm{~mL}$ of buffered peptone water (Difco, USA), and $0.1 \mathrm{~mL}$ portions of diluents were surface plated on McConkey with sorbitol II agar (Difco, USA). The agar plates were incubated at $35^{\circ} \mathrm{C}$ for $48 \mathrm{~h}$.

\section{Kinetic parameters}

The study was repeated twice (replication) with two samples per replication $(n=4)$. Microbiological data (CFU $/ \mathrm{cm}^{2}$ ) were transformed into $\log _{10} \mathrm{CFU} / \mathrm{cm}^{2}$ before being analyzed. Data sets from E. coli O157:H7 growth were fitted to the modified Gompertz model (Gibson et al., 1987) to determine the growth kinetic parameters such as maximum specific growth rate $\left(\mu_{\max }: \log \mathrm{CFU} / \mathrm{cm}^{2} / \mathrm{h}\right)$, lag phase duration (LPD: h), lower asymptote $\left(N_{0}: \log \right.$ $\left.\mathrm{CFU} / \mathrm{cm}^{2}\right)$, and upper asymptote $\left(N_{\max }: \log \mathrm{CFU} / \mathrm{cm}^{2}\right)$. The modified Gompertz model was 


$$
N_{t}=A+C \times \exp \{-\exp [-B(t-M)]\}
$$

where $N_{t}$ is the cell number at any time $t, A$ is the lower asymptotic line of the growth curve as $t$ decreases to zero, $C$ is the difference between the upper asymptotic line of the growth curve and the lower asymptotic line, $B$ is the relative maximum growth rate at time $M$, and $M$ is the time at which the growth rate is maximum (h). Then, $\mu_{\max }, \mathrm{LPD}$, and $N_{\max }$ can be calculated by the equations

$$
\mu_{\max }=\frac{B C}{e}
$$

where $e$ is 2.7182 , and

$$
\begin{aligned}
& \mathrm{LPD}=M-\frac{1}{B} \\
& N_{\text {max }}=A+C
\end{aligned}
$$

\section{Evaluation of growth or no growth}

A total of 56 treatment combinations of storage temperature $\left(13,15,20,25,28,30,33\right.$, and $\left.35^{\circ} \mathrm{C}\right)$ and sampling time $(0,2,4,6,8,10$, and $12 \mathrm{~h})$ were studied. The combinations that allowed increases in cell counts of $E$. coli O157:H7 of at least $0.5 \mathrm{Log} \mathrm{CFU} / \mathrm{cm}^{2}$ compared to the cell counts of E. coli $\mathrm{O} 157: \mathrm{H} 7$ on day 0 were assigned the value of 1 (growth), while the combinations that had increases in cell counts of E. coli $\mathrm{O} 157: \mathrm{H} 7$ of less than $0.5 \mathrm{Log} \mathrm{CFU} / \mathrm{cm}^{2}$ compared to E. coli $\mathrm{O} 157: \mathrm{H} 7$ cell counts on day 0 were given the value of 0 (no growth). Threshold levels of the pathogen cell counts to determine growth and no growth could be altered according to a company's product standard or other considerations, including regulatory standards (Yoon et al., 2011).

\section{Probabilistic model development}

The growth response data (values of 1 or 0 ) were used to develop a probabilistic model to predict E. coli O157:H7 growth probabilities, using the logistic regression analysis of $\mathrm{SAS}^{\circledR}$ version 9.2 (SAS Institute Inc., USA) (Ratkowsky and Ross, 1995). Following equation was derived using the logistic regression analysis, and significant parameters were selected with a stepwise selection method $(p<0.05)$ (Koutsoumanis et al., 2004; McKellar and Lu, 2001).

$$
\begin{aligned}
\operatorname{Logit}(P)= & a_{0}+a_{1} \cdot \text { Temp }+a_{2} \cdot \text { Time }+a_{3} \cdot \text { Temp }^{2} \\
& +a_{4} \cdot \text { Time }^{2}
\end{aligned}
$$

where Logit $(P)$ is an abbreviation of $\ln [P /(1-P)], P$ is the probability of growth (in the range of 0 to 1 ), $a_{i}$ are estimates, Temp is storage temperature, and Time is storage time.

\section{Model validation}

The growth probabilities of E. coli $\mathrm{O} 157: \mathrm{H} 7$ predicted by the model were compared to the observed bacterial populations from other study conducted in our laboratory. In the available data, if a more than $0.5 \mathrm{Log}$ unit increase was observed during storage, it was defined as 'growth' and if a less than $0.5 \mathrm{Log}$ increase in growth or a decline was observed, it was defined as 'no growth'.

\section{Results and Discussion}

\section{Kinetic behavior of $E$. coli $\mathrm{O} 157: \mathrm{H7}$}

Initial bacterial populations of E. coli $\mathrm{O} 157: \mathrm{H} 7$ on polyethylene coupons were approximately $4.0 \mathrm{Log}$ CFU/ $\mathrm{cm}^{2}$ (Table 1; Fig. 1). Obvious growth of E. coli $\mathrm{O} 157: \mathrm{H} 7$ on the coupons were not observed during storage at 13 , 15,20 , and even at $25^{\circ} \mathrm{C}$ for $12 \mathrm{~h}$ (data not shown), but gradual increases in bacterial cell counts of the pathogen were observed approximately up to 5.7 to $7.1 \mathrm{Log}$ CFU/ $\mathrm{cm}^{2}$ at $28,30,33$, and $35^{\circ} \mathrm{C}$ (Table 1 and Fig. 1). Hence, observed growth data only from $28,30,33$, and $35^{\circ} \mathrm{C}$ were fitted to the modified Gompertz model to calculate kinetic parameters, and as expected, E. coli $\mathrm{O} 157: \mathrm{H} 7$ incubated at $28^{\circ} \mathrm{C}$ had longer LPD, and lower $\mu_{\max }$ and $N_{\max }$ values than $30-35^{\circ} \mathrm{C}$ (Table 1 and Fig. 1). The low $N_{\max }$ value at $28^{\circ} \mathrm{C}$ may be caused by decreased affinity for substrates at low temperature because low temperature may inhibit active transport of bacterial cells (George et al., 1996; McClure et al., 1997).

Coefficient of determination $\left(R^{2}\right)$ ranged from 0.821 to 0.969 after fitting the observed data to the modified Gompertz model, and all predicted growth curves passed through most observed data points, regardless of storage temperature (Table 1 and Fig. 1). This indicates that the kinetic model adequately describes biological behavior of E. coli $\mathrm{O} 157: \mathrm{H7}$ on polyethylene coupons, although the $R^{2}$ values are varied. This variation of $R^{2}$ could be caused

Table 1. Kinetic parameters (mean \pm standard deviation) calculated by the modified Gompertz model for Escherichia coli 0157:H7 on polyethylene coupons

\begin{tabular}{cccccc}
\hline \hline $\begin{array}{c}\text { Tem- } \\
\text { perature } \\
\left({ }^{\circ} \mathrm{C}\right)\end{array}$ & $\begin{array}{c}\text { LPD } \\
(\mathrm{d})\end{array}$ & $\begin{array}{c}\mu_{\max } \\
(\log \mathrm{CFU} / \\
\left.\mathrm{cm}^{2} / \mathrm{h}\right)\end{array}$ & $\begin{array}{c}N_{0} \\
(\mathrm{Log} \\
\left.\mathrm{CFU} / \mathrm{cm}^{2}\right)\end{array}$ & $\begin{array}{c}N_{\max } \\
\left(\mathrm{Log} / \mathrm{cm}^{2}\right)\end{array}$ & $R^{2}$ \\
\hline 28 & $7.20 \pm 0.0$ & $0.42 \pm 0.0$ & $4.2 \pm 0.2$ & $5.7 \pm 0.0$ & 0.821 \\
30 & $4.31 \pm 1.08$ & $0.52 \pm 0.26$ & $4.3 \pm 0.0$ & $7.1 \pm 0.1$ & 0.969 \\
33 & $4.94 \pm 0.42$ & $2.06 \pm 1.08$ & $3.8 \pm 0.1$ & $6.5 \pm 0.1$ & 0.922 \\
35 & $5.89 \pm 2.07$ & $1.32 \pm 1.3$ & $3.9 \pm 0.3$ & $6.6 \pm 0.7$ & 0.840 \\
\hline
\end{tabular}

$\mu_{\max }$, maximum specific growth rate; LPD, lag phase duration; $N_{0}$, lower asymptote; $N_{\max }$, upper asymptote 

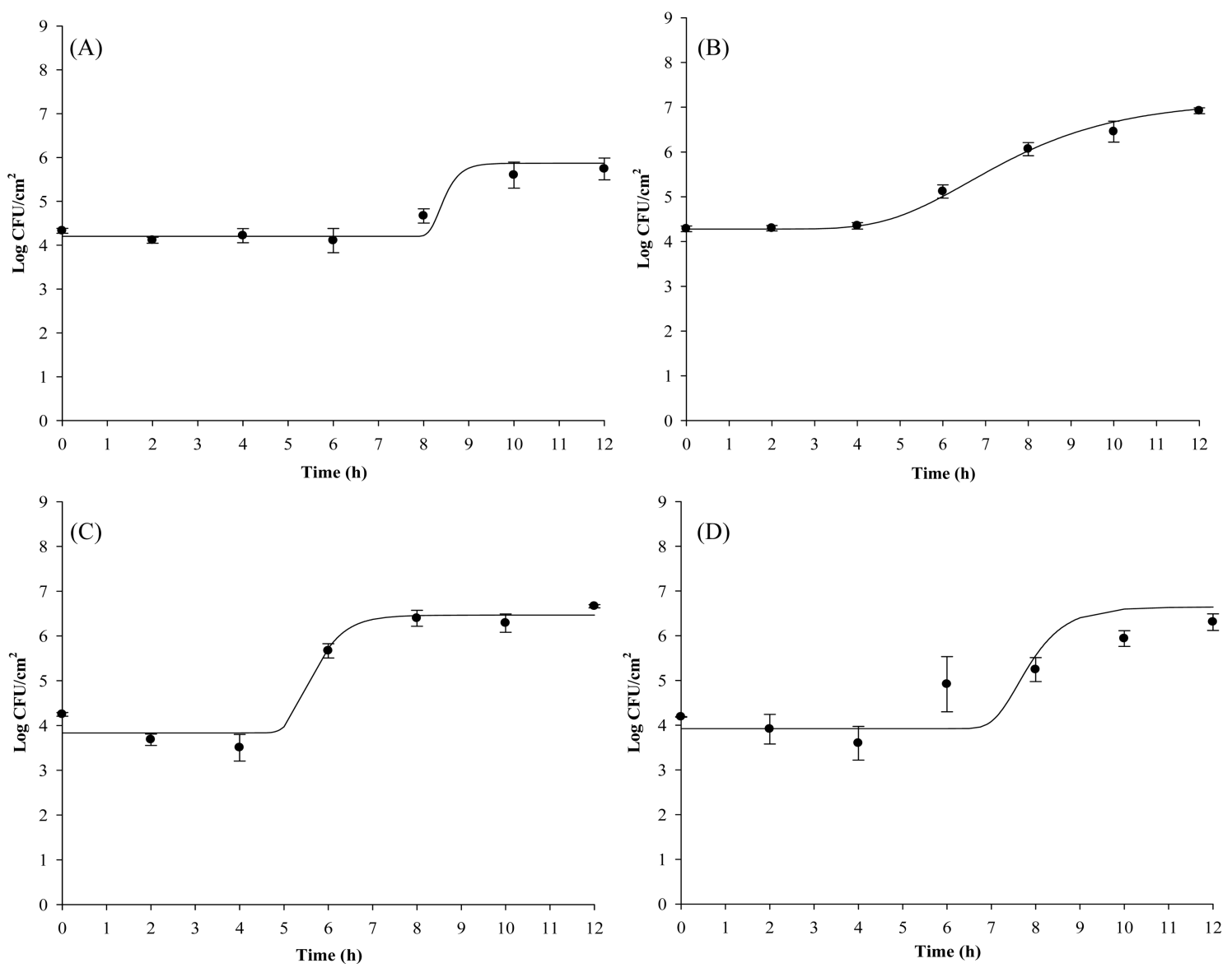

Fig. 1. Bacterial populations (symbols) of Escherichia coli O157:H7 recovered with McConkey with sorbitol II agar from polyethylene coupons and predicted cell counts (line) by the modified Gompertz model during $12 \mathrm{~h}$ of incubation at $28^{\circ} \mathrm{C}(\mathrm{A})$, $30^{\circ} \mathrm{C}(\mathrm{B}), 33^{\circ} \mathrm{C}(\mathrm{C})$, and $35^{\circ} \mathrm{C}(\mathrm{D})$; only temperatures, which showed growth of the pathogen, are presented.

by the competition between various natural flora and $E$. coli $\mathrm{O} 157: \mathrm{H} 7$ called the James effect, which is a race between bacterial species to use the resources of the environment (Coleman et al., 2003; Cornu et al., 2011). The majority of mathematical equations have been used for fitting data from liquid laboratory media which produce good fitting results, but interactions between indigenous microflora and pathogens in foods and food-related conditions should be considered to develop practical models because indigenous microflora may influence fates of foodborne pathogens (Cornu et al., 2011; Yoon et al., 2009).

According to the results from Fig. 1, following implication can be introduced. Even though E. coli O157:H7 cells are contaminated on polyethylene cutting board, the pathogen may not proliferate up to $12 \mathrm{~h}$, if cells of the pathogen are exposed to less than $25^{\circ} \mathrm{C}$.

\section{Probabilistic model}

To calculate growth probability of $E$. coli $\mathrm{O} 157: \mathrm{H} 7$ on polyethylene coupons, estimates of coefficients were determined by stepwise selection method after analyzing binary growth response data with the logistic regression analysis (Table 2). The estimates were then used to calculate probabilities of $E$. coli $\mathrm{O} 157: \mathrm{H} 7$ growth on polyethylene coupons, and the predicted interfaces between growth and no growth of $E$. coli $\mathrm{O} 157: \mathrm{H} 7$ at $0.1,0.5$, and 0.9 of probabilities were produced as a function of temperature and time (Fig. 2). This result can be used to predict combinations of upper limits of working temperature and exposure time to inhibit E. coli $\mathrm{O} 157: \mathrm{H} 7$ growth on polyethylene cutting board at a desired probability of

Table 2. Estimates of parameters selected from the logistic regression analysis by a stepwise selection method to calculate growth probabilities of Escherichia coli 0157:H7 on polyethylene coupons

\begin{tabular}{lrcr}
\hline \hline \multicolumn{1}{c}{ Coefficient } & Estimate & Standard error & $p$-value \\
\hline Intercept & -242.1 & 63.0621 & 0.0001 \\
Temperature & 14.6311 & 3.9472 & 0.0002 \\
Time & 1.5252 & 0.3600 & $<0.0001$ \\
TemperaturexTemperature & -0.2284 & 0.0632 & 0.0003 \\
\hline
\end{tabular}




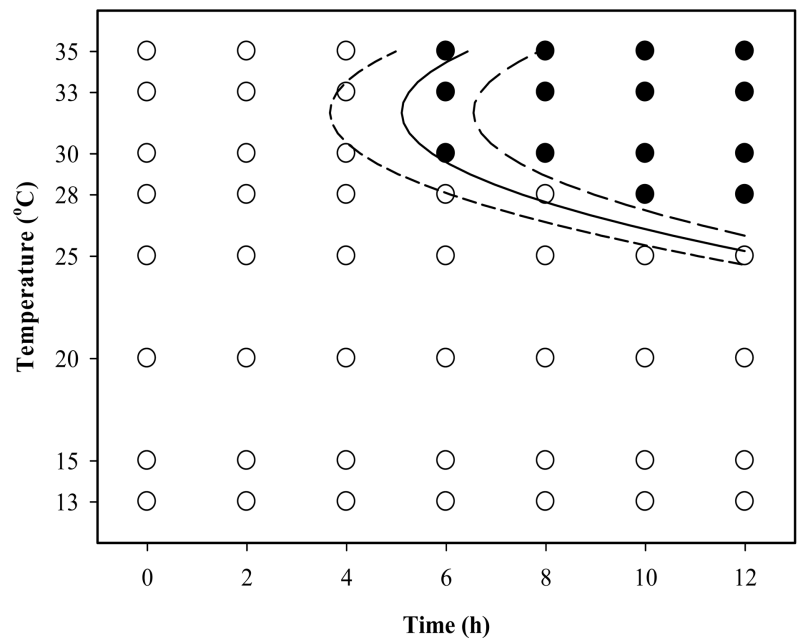

Fig. 2. The observed growth response (growth: $\bullet$, no growth: O) of Escherichia coli O157:H7 on polyethylene coupons stored at $13,15,20,25,28,30,33$, and $35^{\circ} \mathrm{C}$ up to $12 \mathrm{~h}$, and interfaces between growth and no growth with respect to temperature and time as predicted by the developed probabilistic model using the equation 5 at growth probabilities of 0.1 (lower line), 0.5 (middle line), and 0.9 (upper line).

growth. For instance, E. coli $\mathrm{O} 157: \mathrm{H} 7$ started to grow after $10 \mathrm{~h}$ of incubation at between $25^{\circ} \mathrm{C}$ and $28^{\circ} \mathrm{C}$ at 0.5 of probability, and at higher incubation temperature $E$. coli $\mathrm{O} 157: \mathrm{H} 7$ growth was observed between 6 and $8 \mathrm{~h}$ of incubation at 0.5 probability (Fig. 2). If the probability of 0.5 is considered liberal, more conservative probability can be used (Tienungoon et al., 2000). This indicates that with consideration of the growth inhibiting E. coli O157:H7 on cutting boards the temperature in working area of butcher's shops should be determined according to the length of working hour rather than applying only $15^{\circ} \mathrm{C}$ as indicated in the regulation of QIA (2009).

\section{Probabilistic model performance}

Goodness of fit of the developed probabilistic model was measured by the concordance index showing the degree of agreement between the predicted probabilities and the observed responses (Koutsoumanis et al., 2004). For the developed probabilistic model in this study, the degree of agreement between the predicted probabilities and the observations was $99.3 \%$ and $0.6 \%$ of discordance was observed (data not shown). For further evaluation of model performance, the predicted growth probabilities calculated by the developed model were compared to the observed growth response data on which the model was based (Koutsoumanis et al., 2004). This result showed that one observed growth response $(1.79 \%)$ of 56 combinations disagreed with the model prediction; in the model
Table 3. Comparison between observed responses of Escherichia coli 0157:H7 on polyethylene coupons and growth probability of the pathogen predicted by the developed probabilistic model

\begin{tabular}{crlc}
\hline \hline $\begin{array}{c}\text { Temperature } \\
\left({ }^{\circ} \mathrm{C}\right)\end{array}$ & $\begin{array}{c}\text { Time } \\
(\mathrm{h})\end{array}$ & $\begin{array}{l}\text { Observed } \\
\text { response }\end{array}$ & $\begin{array}{c}\text { Predicted probability } \\
\text { of growth }\end{array}$ \\
\hline 18 & 9 & No growth & 0.0 \\
\hline & 1 & No growth & 0.0 \\
28 & 5 & No growth & 0.0 \\
& 9 & Growth & 0.903 \\
& 11 & Growth & 0.995 \\
\hline \multirow{3}{*}{32} & 3 & No growth & 0.0 \\
& 7 & Growth & 0.947 \\
& 9 & Growth & 0.997 \\
& 11 & Growth & 1.0 \\
\hline 35 & 1 & No growth & 0.0 \\
& 5 & No growth & 0.102 \\
& 7 & Growth & 0.706 \\
& 11 & Growth & 0.999 \\
\hline
\end{tabular}

prediction growth or no growth of the combinations were determined at 0.5 of growth probability (Koutsoumanis et al., 2004; Yoon et al., 2009; Yoon et al., 2011). The developed probabilistic model predicting growth probability of $E$. coli $\mathrm{O} 157: \mathrm{H} 7$ was validated with the data from other study in our laboratory, and the model displayed agreement with most growth responses of $E$. coli O157:H7 on polyethylene coupons (Table 3).

In conclusion, this study provides quantitative data of E. coli $\mathrm{O} 157: \mathrm{H} 7$ growth on the polyethylene cutting board incorporating working hour and temperature, and the interfaces between growth and no growth of the pathogen at various probabilities. Therefore, the results should be useful in determining upper limits of working temperature and time not to allow E. coli $\mathrm{O} 157: \mathrm{H} 7$ growth on polyethylene cutting board, which could be useful information in food safety management system, especially for small-scale butcher's shops.

\section{Acknowledgements}

This research was supported by the Sookmyung Women's University Research Grants 2011, and Technology Development Program for High Value-added Food (111018-031-WT111), Ministry for Food, Agriculture, Forestry and Fisheries, Republic of Korea.

\section{References}

1. Baranyi, J. and Roberts, T. A. (1994) A dynamic approach to 
predicting bacterial growth in food. Int. J. Food Microbiol. 23, 277-294.

2. Bryan, F. L. (1990) Hazard Analysis Critical Control Point (HACCP) system for retail food and restaurant operations. $J$. Food Prot. 53, 978-983.

3. Coleman, M. E., Sandberg, S., and Anderson, S. A. (2003) Impact of microbial ecology of meat and poultry products on predictions from exposure assessment scenarios for refrigerated storage. Risk Anal. 23, 215-228.

4. Cornu, M., Billoir, E., Bergis, H., Beaufort, A., and Zuliani, V. (2011) Modeling microbial competition in food: Application to the behavior of Listeria monocytogenes and lactic acid flora in pork meat products. Food Microbiol. 28, 639647.

5. Deboosere, N., Pinon, A., Delobel, A., Temmam, S., Morin, T., Merle, G., Blaise-Boisseau S., Perelle, S., and Vialette, M. (2010) A predictive microbiology approach for thermal inactivation of Hepatitis A virus in acidified berries. Food Microbiol. 27, 962-967.

6. FSA (Food Standards Agency). (2011) HACCP in meat plants. Available at; http://www.food.gov.uk/ food-industry/ meat/haccpmeatplants/. Accessed on November 30, 2011.

7. Genigeorgis, C., Martin, S., Franti, C. E., and Riemann, H. (1971) Initiation of staphylococcal growth in laboratory media. Appl. Microbiol. 21, 934-939.

8. George, S. M., Richardson, L. C. C., and Peck, M. W. (1996) Predictive models for the effect of temperature, $\mathrm{pH}$, and acetic and lactic acids on the growth of Listeria monocytogenes. Int. J. Food Microbiol. 32, 73-90.

9. Gibson, A. M., Bratchell, N., and Roberts, T. A. (1987) The effect of sodium chloride and temperature on the rate and extent of growth of Clostridium botulinum type A in pasteurized pork slurry. J. Appl. Bacteriol. 62, 479-490.

10. Gounadakia, A. S., Skandamis, P. N., Drosinos, E. H., and Nychas, G-J. (2008) Microbial ecology of food contact surfaces and products of small-scale facilities producing traditional sausages. Food Microbiol. 21, 313-323.

11. Koutsoumanis, K. P., Kendall, P. A., and Sofos, J. N. (2004) A comparative study on growth limits of Listeria monocytogenes as affected by temperature, $\mathrm{pH}$ and $\mathrm{a}_{\mathrm{w}}$ when grown in suspension or on a solid surface. Food Microbiol. 21, 415422.

12. Koutsoumanis, K., Pavlis, A., Nychas, G-J. E., and Xanthiakos, K. (2010) Probabilistic model for Listeria monocytogenes growth during distribution, retail storage, and domestic storage of pasteurized milk. Appl. Environ. Microb. 76, 2181-2191.
13. Mataragas, M., Drosinos, E. H., Siana, P., Skandamis, P., and Metaxopoulos, I. (2006) Determination of the growth limits and kinetic behavior of Listeria monocytogenes in a sliced cooked cured meat product: validation of the predictive growth model under constant and dynamic temperature storage conditions. J. Food Prot. 69, 1312-1321.

14. McClure, P. J., Beaumont, A. L., Sutherland, J. P., and Roberts, T. A. (1997) Predictive modelling of growth of Listeria monocytogenes: the effects on growth of $\mathrm{NaCl}, \mathrm{pH}$, storage temperature and sodium nitrate. Int. J. Food Microbiol. 34, 221-232.

15. McKellar, R. C. and Lu, X. (2001) A probability of growth model for Escherichia coli O157:H7 as a function of temperature, pH, acetic acid, and salt. J. Food Prot. 64, 1922-1928.

16. QIA (Animal, Plant and Fisheries and Quarantine and Inspection Agency) (2009) QIA regulation No. 2009-9. Livestock product HACCP standard.

17. Ratkowsky, D. A. and Ross, T. (1995) Modelling the bacterial growth/no growth interface. Lett. Appl. Microbiol. 20, 29-33.

18. Tang, J. Y., Nishibuchi, M., Nakaguchi, Y., Ghazali, F. M., Saleha, A. A., and Son, R. (2011) Transfer of Campylobacter jejuni from raw to cooked chicken via wood and plastic cutting boards. Lett. Appl. Microbiol. 52, 581-588.

19. Tienungoon, S., Ratkowsky, D. A., McMeekin, T. A., and Ross, T. (2000) Growth limits of Listeria monocytogenes as a function of temperature, $\mathrm{pH}, \mathrm{NaCl}$, and lactic acid. Appl. Environ. Microb. 66, 4979-4987.

20. Yoon, Y., Geornaras, I., Scanga, J. A., Belk, K. E., Smith, G. C., Kendall, P. A., and Sofos, J. N. (2011) Probabilistic models for the prediction of target growth interfaces of Listeria monocytogenes on ham and turkey breast products. J. Food Sci. 76, M450-M455.

21. Yoon, Y., Kendall, P. A., Belk, K. E., Scanga, J. A., Smith, G. C., and Sofos, J. N. (2009) Modeling the growth/no growth boundaries of postprocessing Listeria monocytogenes contamination on frankfurters and bologna treated with lactic acid. Appl. Environ. Microb. 75, 353-358.

22. Yoon, Y. and Sofos, J. N. (2008) Autoinducer-2-activity of gram-negative foodborne pathogenic bacteria and its influence on biofilm formation. J. Food Sci. 73, M140-M147.

23. Zhao, T., Zhao, P., Cannon, J. L., and Doyle, M. P. (2011) Inactivation of Salmonella in biofilms and on chicken cages and preharvest poultry by levulinic acid and sodium dodecyl sulfate. J. Food Prot. 74, 2024-2030.

(Received 2011.12.12/Revised 2012.2.7/Accepted 2012.2.16) 